\title{
“Días de asueto: esparcimiento, descansos regeneradores y viajes de placer en la obra de Emilia Pardo Bazán”
}

\author{
Javier López Quintáns
}

\begin{abstract}
La vida contemporánea, es hacer la maleta e irse por esos mundos... Los periódicos no hablan sino de expediciones; no hay quien en estos momentos no se dirija aquí o acullá, adentro o afuera, según sus aficiones, gustos y necesidades. Los unos se van a las playas, donde se respira anchamente la brisa salitrosa; los otros prefieren lo aires puros y fríos de la sierra; estos se lanzan a arrostrar los precios exorbitantes de la Exposición (...); aquéllos, más cautos o ahorrotes, se encierran en sus casas, abrazados a la jarra del agua fresca, y aguardan a que pase el sofocón que nos abruma" ("La vida contemporánea. Viajes. Chinitos. El calor. Echegaray", La Ilustración Artística, número 971, 6 de agosto de 1900, pág. 506 ${ }^{\mathbf{I}}$ ).
\end{abstract}

1. Presentación.

2. Turismo de motivación religiosa.

3. Turismo heliotrópico.

4. Viajes en invierno.

5. Turismo cultural: viajes por la geografía hispánica y europea.

6. Turismo termal.

7. Excursionismo: jiras campestres y días de campo.

8. El problema de los medios de transporte.

9. Instalaciones hoteleras.

10. Viajeros ilustres.

11. Conclusiones.

\section{PRESENTACIÓN}

La gran variedad de tipos y situaciones que germinan en la obra ficticia y periodística de Pardo Bazán aparecen en multitud de ocasiones marcados por una existencia sacrificada, condicionada por el trabajo: trabajo para mejorar socialmente (Los tres arcos de Cirilo), para cumplir sueños ("La dama joven"), para lucrarse (El becerro de metal), para olvidar las penas del

\footnotetext{
${ }^{\text {I }}$ Cito por la edición facsimilar de la Hemeroteca Municipal de Madrid, pág. 163.
}

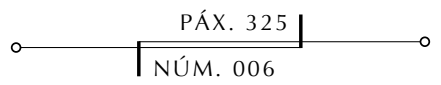


pasado ("Perlista", "Bromita"), para (simplemente) subsistir en un entorno duro, difícil, adverso y, a ratos, absurdo (La tribuna, "Inútil", "Accidente", "Un duro falso", "Planta montés"). Trabajo que, por supuesto, se difumina o desaparece en el universo poblado por seres ociosos: burgueses (El cisne de Vilamorta, Allende la verdad, Un drama), aristócratas (Un viaje de novios, Los Pazos de Ulloa, La madre naturaleza, La sirena negra, El saludo de las brujas, Clavileño, Verdad, Cuesta abajo, "El conde Ilora", "El conde sueña", "La armadura", "Juan Trigo") o meros vagos y crápulas que planean como aves de rapiña sobre individuos cuya prosperidad crematística se convierte en objeto de deseo (La aventura de Isidro, "Presentido", "En coche-cama"). Todos ellos, unos y otros, los sufrientes proletarios, los profesionales instruidos, junto a los privilegiados nutridos con rentas o engaños, atraviesan una vida cotidiana cuya rutina ansían romper momentáneamente. Aquí aparecen los días de campo, el fin de semana reparador, los viajes.

La producción de Emilia Pardo Bazán reviste un indudable interés antropológico y sociológico, en tanto que testimonio de una época. Por ello, el presente trabajo aborda el análisis del turismo como fenómeno de antepasados reconocidos, en especial el esparcimiento y el goce del espacio libre del que se disponía (la skholé griega, el otium romano...) y una idiosincrasia tal, según la conocemos hoy, forjada con la modernidad industrial, pues se viene señalando la década de los 40 en el siglo XIX como arranque de un turismo más o menos organizado. No es objeto de este trabajo detener al autor sobre la evolución de dicho fenómeno, más propio quizás de un estudio bajo el amparo de la sociología del ocio o la sociología del turismo, sino tan sólo ponerle al tanto de la información que al respecto nos proporciona Pardo Bazán, en tanto que ilustración de lo que acontecía en su época. Para ello, parto de los siguientes principios, que invito a tener muy en cuenta para entender el sentido de este trabajo ${ }^{2}$ :

1. Concepción del turismo como desplazamiento fisico superior a veinticuatro horas e inferior a un año, que abarca (siempre desde mi punto de vista, y para los intereses de este artículo) desde el simple excursionismo hasta las giras propias de ciertas clases acomodadas por Europa (en lo que destaca especialmente la aristocracia inglesa). El

2 Tomo como referencia autores como Anderson (1975), Cohen (1974), Fernández Fuster (1991), Murphy (1985), Ryan (1991) o Tezanos, (2003), entre otros. 


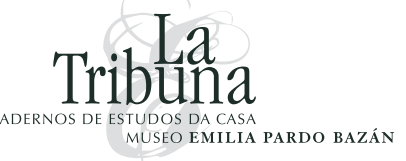

galicismo inglés "tour" tiene su nacimiento embrionario en el arranque del siglo XIX, y la propia idea de turismo se forjará precisamente en este siglo. Será ya en el XX cuando cobra consistencia el turismo de masas, sobre el que no me detendré, por estar alejado de la época de Pardo Bazán.

2. Inclinación por algunas de las manifestaciones propias de este fenómeno, ajustándome a las clasificaciones más reconocidas, para dar cuenta al cabo de cómo Pardo Bazán testimonia en su producción periodística (y ficcionalmente en su obra literaria) dicho fenómeno. Así, hablo del turismo heliotrópico (o de sol), del turismo termal, del turismo cultural o del turismo de motivación religiosa, a los que añado el simple y mero excursionismo (sin entrar a discutir si debe ser acogido bajo el amparo del concepto turismo, y reconociendo indudablemente su condición de desplazamiento, por el mero placer recreativo en el paisaje) y el turismo en época invernal, como manifestaciones fundamentales para entender el turismo en las tres últimas décadas del XIX y las dos primeras del XX. Sobre ellos se centrarán los sucesivos apartados de este artículo. Dejo de lado el análisis de una manifestación de interés (de ello da cuenta la producción de los autores románticos), el turismo a lugares exóticos, por no aportar Pardo Bazán reflexiones reseñables; igual causa explica la exclusión del turismo de nieve, que goza de especial predicamento a partir del siglo XX.

Me centro, así pues, en los textos de Pardo Bazán por el innegable valor testimonial que aportan. La autora gallega nos ha dejado unas significativas muestras de libros de viajes (algunos de ellos recopilación de artículos que había publicado en la prensa), entre los que podemos destacar Apuntes de un viaje. De España a Ginebra (1873)³, Mi romería (1888), De mi tierra (1888), Al

${ }^{3}$ Es un texto inédito. Véase González Herrán (1999 y 2000): “(...) ese diario de viaxe nunca chegou a publicarse e a súa existencia era descoñecida ata datas recentes: entre os papeis de dona Emilia depositados na sede coruñesa da Real Academia Galega encóntranse uns Apuntes de un viaje. De España a Ginebra (así titulados no manuscrito), dos que ofrecín noticia e primicias en setembro de 1996. Tras aquel título, e a precisa indicación do día en que se inicia, " $1^{\circ}$ de Enero de 1873», comeza así: "Para no faltar desde el primer día a la palabra que os he dado de no omitir en estos rápidos apuntes el más pequeño detalle de mi viaje, mi cuaderno preparado y mi lápiz cortado recientemente descansaban en mis rodillas cuando la diligencia se puso en marcha» (en González Herrán, 1999: 180). Desde Ourense e nesa dilixencia, os expedicionarios (Emilia, os seus pais, un tío e mailo seu esposo) diríxense, por Allariz, Xinzo de Limia, Verín, o difícil paso das Portillas e Puebla de Sanabria, ata Zamora, onde tomarán o tren para Burgos” (2000: 181). 
pie de la torre Eiffel (1889), Por Francia y por Alemania (1889), Días Toledanos (1891), Por la España pintoresca (1896), Cuarenta días en la exposición (1901), o Por la Europa católica (1902), entre otros. Este trabajo se ocupa de ellos ${ }^{4}$. Me detengo en aquellas alusiones (esporádicas o amplias) que la autora gallega realiza en algunas de sus colaboraciones periodísticas y críticas (no recogidas en sus libros de viajes, como "El viaje por España", publicado en noviembre de 1895 en La España Moderna; los artículos editados en Letras de molde en 1900, centrados en el Levante; o varios artículos sueltos en La Ilustración Artística no recogidos en libro, que iremos detallando) y en las que después aparecen como volumen (tengan o no su antecedente en la prensa). Alguna cita extraída de su obra literaria redondeará lo que vayamos viendo. Propongo además un texto que, si bien totalmente alejado del género de los libros de viajes, me permitirá ilustrar unos de los flujos turísticos más importantes en la historia de la humanidad: los de índole religiosa. Me refiero a La leyenda de la Pastoriza (1887).

Así pues, he rastreado aquellas alusiones en las que la escritora gallega describe momentos de descanso, de esparcimiento, de asueto, ya bien sean con un fin intelectual (visitas a monumentos, lugares históricos, reliquias del pasado o proyectos del presente entre los que sobresalen las Exposiciones Universales), médico o higiénico (estancias en balnearios), o meramente prosaico (excursiones campestres, viajes de novios, romerías...). La autora lamentará la ausencia de viajeros "porque sí", por un mero deseo de realización personal, de complemento cultural. Sólo una escasa minoría manifiesta estos gustos, mientras que el resto, tal y como apunta en Por la Europa Católica ("Castilla"), lo hacen por un motivo "penal" (es decir, por obligación), o desde una perspectiva "fashionable" [sic.] (respuesta a una moda, como imitación a otros). Pero veámoslo. Empecemos, así pues, nuestro viaje.

\section{TURISMO DE MOTIVACIÓN RELIGIOSA.}

Los viajes con un fin devocionario cuentan con una amplia tradición en la historia de la humanidad, muy vinculado en la tradición cristiana con la modificación del concepto de la peregrinatio (viaje, desplazamiento)

4 En este sentido, debemos destacar algunos estudios fundamentales publicados sobre este tema, como los de Freire López (1999) y González Herrán (2000).

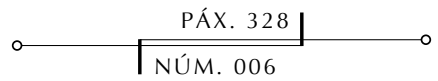




\section{Tribuna}

del mundo romano. El mundo cristiano conocerá un auge progresivo de los desplazamientos por motivaciones religiosas, con hitos fundamentales como el camino de Santiago (ciudad de la que me ocuparé en el apartado de "Turismo cultural") o Jerusalén, pero también Lourdes o Fátima. Condicionados por la elección voluntaria e intencionada de la obra de Pardo Bazán, aportaremos una visión inevitablemente sesgada por cierto toque etnocentrista y una visión netamente occidental. Ello no será obstáculo para que se mencione, aunque sea sólo de pasada, la existencia del "peregrinaje" religioso (el concepto debería ser perfilado según el contexto) en diferentes culturas, dígase islámica (a la Meca) o hindú (fuentes del Ganges), o incluso el practicado en civilizaciones perdidas como la maya (a Chichón Itzá).

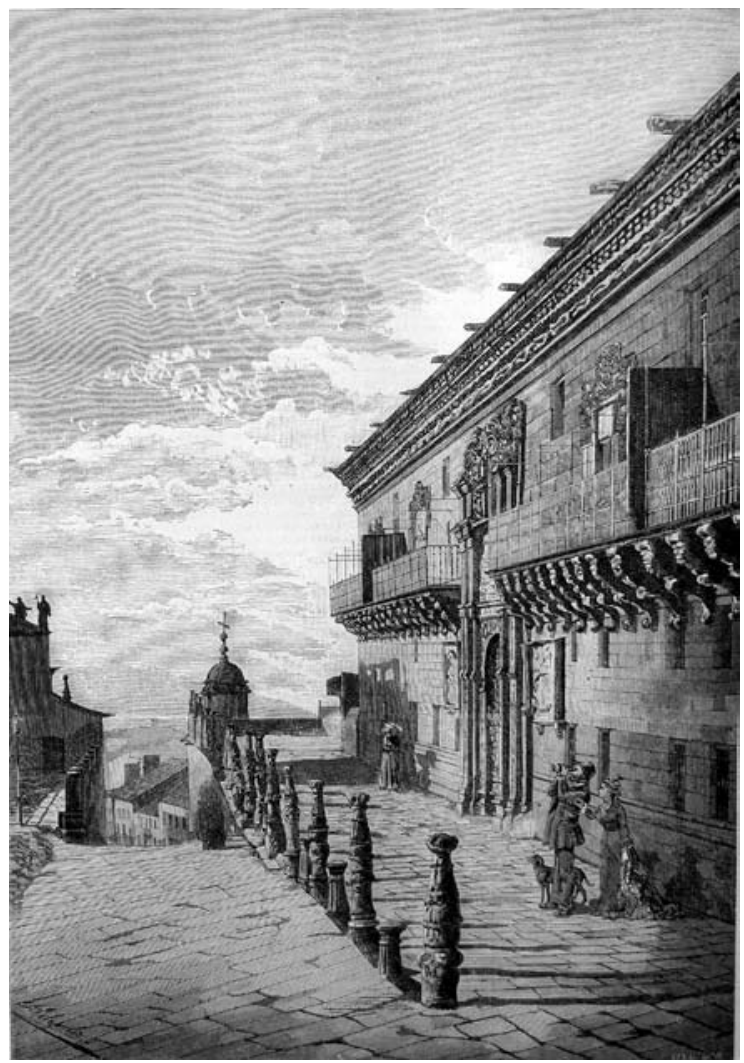

Fachada do Real Hospital de Santiago. Gravado. La Ilustración Gallega y Asturiana, 10/05/1879, páxina 150. Biblioteca da Real Academia Galega. 
La obra de Pardo Bazán nos permite ilustrar el concepto de peregrinaje en el cristianismo y la desvirtualización del mismo (de viaje movido por la fe a manifestación ociosa y de placer, como subrayo en el apartado de "Turismo cultural"). Según anunciaba en la introducción, podemos identificar un ejemplo indirecto con La leyenda de la Pastoriza. Nos sirve de muestra de la especial relevancia que ha tenido el culto a la Virgen María, causa primera de algunos de los peregrinajes más importantes en Europa occidental (NotreDamme, París; Catedral de la Virgen, Munich; Iglesia de Nuestra Señora, Brujas; Santa María del Fiore, Florencia; Nuestra Señora del Pilar, Zaragoza; Santa María Asunta, Pisa; Nuestra Señora de la Guardia, Marsella; etc). De este modo, la autora coruñesa cita en La leyenda de la Pastoriza vírgenes gallegas (Nuestra Señora del Corpiño, la Virgen de la Barca, la Virgen del Cristal..., pág. 8), y muestra su propia devoción en el santuario al depositar la corona de laurel que había recibido del Círculo Mercantil de Coruña (pág. 11).

La Virgen del lugar ocupará la atención del libro, desde diversas perspectivas: una legendaria, pues es el párroco, don Víctor Cortuela, el que le narra las leyendas atribuidas a la Virgen (pág. 15); otra artística, focalizada en el valor de la talla que allí se conserva (es la primera efigie cristiana que recibió culto en Galicia, según Pardo Bazán, con una antigüedad de 15 siglos, pp. 23-24); finalmente, otra de índole religiosa, como centro de culto y peregrinaje, manifestación esta muy vinculada con las dos anteriores puesto que todas ellas se combinan y complementan como elementos de reclamo.

Dado que se trata de un texto prácticamente olvidado en la actualidad, creo de interés reseñar brevemente su contenido. El libro consta de los siguientes capítulos:

I: "La vírgenes milagrosas", comentario sobre diferentes cultos a la Virgen María.

II: "Como se me ocurrió escribir esta leyenda", constatación de la ofrenda que la autora acerca al santuario, y buena muestra de un tipo de impulso que condiciona el peregrinaje religioso.

III: "Historia", centrada en la evolución del santuario (la caída del Imperio Romano, la llegada de suevos, o el culto a la imagen).

IV: "La cuna de la Virgen", descripción del lugar donde se encuentra la talla, y el panorama que se avista alrededor del santuario.

V: "La Pastoriza", que muestra el culto religioso de los pastores, y en especial la devoción por la imagen.

VI: "El milagro del Draque", que constata los hechos históricos de 1859. En ese año, el famoso pirata Drake ataca Coruña. Según el texto, sus hombres decapitan la imagen pero esta se reconstruye milagrosamente.

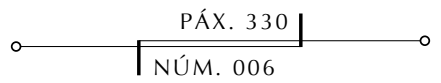


VII: "La imagen antes y ahora", dedicado al capitán Juan del Río, reformador de la iglesia, aunque según el librillo no siempre acertadamente. A continuación se detalla el estado presente de la imagen.

VIII: "La cabeza de la Virgen", que incluye otra leyenda sobre un capitán de un barco que, obsesionado, robó la cabeza.

IX: "La inscripción", que indica que de la iglesia anterior del siglo XVIII queda una inscripción, y se ofrecen detalles de ésta.

X: "La Virgen de granito", donde se anuncia que habrá nueva estatua, donación de Álvaro Torres de Tabeada y obra de José Couto.

XI: "El santuario", dedicado a la descripción de la fachada y del interior, así como de la devoción que despierta la Virgen de la ermita.

Muchos otros son los ejemplos que la escritora nos ofrece en torno al fenómeno del peregrinaje religioso, o más concretamente a la visita por cuestiones de devoción o de culto religioso, de ahí que en sus testimonios se entremezcle este último motivo con la del excursionismo simple o la visita de intención cultural (dígase observación del valor arquitectónico del edificio). De carácter religioso a la par que cultural se reviste su visita a Medina de Rioseco según aduce en Por la España Pintoresca, donde acude a los templos de Santa María, Santiago, Santa Cruz y San Francisco; y de igual forma describe el templo de San Pedro das Rocas, que no despierta especialmente su interés; o la iglesia de San Francisco en Betanzos.

Finalmente, como última muestra de este apartado, creo necesario indicar que significativo peregrinaje religioso es su viaje a Roma, con motivo del jubileo sacerdotal de León XIII, en 1887, en Mi romería. Texto que reviste interés por la descripción de figuras humanas ("La romería en siluetas", por ejemplo, en donde habla de "microcosmos donde sin gran esfuerzo veo representados muchos y muy distintos aspectos del espíritu católico"), de templos (San Juan de Letrán en "La iglesia madre"; San Pedro en "El fantasma blanco"); los sentimientos que brotan por el viaje y la visión del Papa ("El fantasma blanco"; "Una audiencia y una grilla"); o las ruinas de la era romana, inclusive catacumbas ("Dos muertes"; "Un cicerone gratis"). En su viaje hallamos alusiones a paradas en otros lugares de reconocido valor religioso, como Lourdes en "Una salve" y "Acqua Vergine". De extremo interés es este último capítulo, en tanto que muestra el entorno comercial y mercadotécnico que rodea a los núcleos religiosos: alojamientos, restaurantes, y sobre todo venta de objetos (rosarios, agua embotellada...), fenómeno que pervive en la actualidad, y viene a ser muestra del mercantilismo que rodea a todo este tipo de peregrinajes. Llamo la atención sobre que Pardo Bazán constata este 
fenómeno, como observadora, pero no cuestiona ni censura decididamente estas prácticas 5 .

\section{TURISMO HELIOTRÓPICO}

El fenómeno del turismo heliotrópico está ampliamente arraigado en el siglo XX (también en el XXI), de la mano de manifestaciones paralelas como el turismo de masas o la especulación urbanística. Pero este turismo de sol, de viaje a las playas, está ampliamente documentado ya en el siglo XIX. La autora coruñesa alude a alguno de los destinos predilectos (costas vasca y cántabra), y nos aporta una estampa muy precisa de la imagen que estos ofrecen. De esta manera, destaca su apariencia populosa, el bullicio que puebla dichas zonas, como ocurre en la de San Sebastián ${ }^{6}$, a veces rayando el pintoresquismo (díganse los detalles sobre la vestimenta de los bañistas o la presencia de accesorios como sombrillas, en "La vida contemporánea. San Sebastián", pág. 6627; o incluso la denuncia de la presencia de mirones o lo inadecuado de ciertos trajes ("La vida contemporánea. San Sebastián", pág. 662 ", "La vida contemporánea. Marinas", pág. 56299), de cuya crítica se salvan tan sólo las bañistas procedentes de la montaña por la compasión que le despiertan ("La Nación. Crónica de España. Un mitin contra la guerra. El veraneo", p. $5^{\text {ro)}) . ~}$

De igual forma anotará estampas de playas extranjeras como la de Biarritz, reclamo turístico por ser lugar elegido por Napoleón III (de igual forma que San Sebastián se popularizó por las visitas de la familia real española). Nos

\footnotetext{
5 Pardo Bazán describirá, además, romerías populares como la de San Isidro, en cuentos como "En el santo", 321, o Insolación, 111-112.

${ }^{6}$ Galdós da cuenta del interés por San Sebastián, y menciona el traslado del Rey a Betelu y de la Corte a la Granja (Carta en La Prensa de Buenos Aires, 17 de agosto de 1885). El movimiento de la Corte a La Granja aparece constatado en otros artículos, caso de "Partida de la corte. Estado de Madrid. Expedición veraniega (...)" ("Folletín. Revista de Madrid", La Nación. Diario Progresista, 9 de julio de 1865). También comenta la marcha de la Corte a Zarauz ("Inacción en la política y en los teatros", "Folletín. Revista de la semana”, La Nación. Diario Progresista, 23 de julio de 1865). Comentará el regreso de los veraneantes de París, Suiza..., aludiendo a la imagen de los ferrocarriles que los trasportan ("El verano se despide. Lucha de las estaciones (...)", "Folletín. Revista de la semana", La Nación. Diario Progresista, 10 de septiembre de 1865).

${ }^{7}$ La Ilustración Artística, número 718, 30 de septiembre de 1895, ed. cit., pág. 46.

${ }^{8}$ La Ilustración Artística, número 718, 30 de septiembre de 1895, ed. cit., pág. 46.

9 La Ilustración Artística, número 764, 17 de agosto de 1896, ed. cit., pág. 61.

Io La Nación, Buenos Aires, 9 de septiembre de 1911, ed. cit., 573.
}

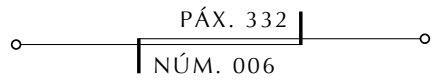


interesa conocer como los españoles frecuentaban esta playa, sobre todo en julio y agosto, para dejar paso en septiembre a los ingleses ("La vida contemporánea. Biarritz", pág. 694 ${ }^{\text {II }}$ ). El fenómeno del flujo heliotrópico se ilustra con otras playas, como Etretat, Trouville, la Barcelonesa, Arcachón, Espinho, Figueira, Vilagarcía de Arousa, las Arenas o el Sardinero (pág. $562^{\text {I2 }}$ ), pero más interesante resulta que vincule su época con un interés por los baños termales o en el mar. En ello tiene mucho que ver el aumento de una confianza general en la salubridad de las aguas, impulsado por medios científicos cuyas resonancias tuvieron cabida en la prensa. En este sentido, el higienismo, como corriente científica, nace en el siglo XIX con hitos precedentes como La miseria del pueblo (1790) de Johan Meter Frank, teorías que tendrán su eco en Koch o Pasteur. En suma, el interés creciente por una salubridad pública centrará su esfuerzo en la purificación de las aguas, lo que conlleva el uso de las termales y, con posterioridad, de baños en el mar. Notamos la presencia de esas teorías en Pardo Bazán, pues resalta los efectos balsámicos de los baños de mar, frente a lo que se creía poco menos que un siglo antes ("La vida contemporánea. Marinas", pág. 562³3).

Muchos otros son los lugares que la escritora detalla, caso de las playas portuguesas, muestra de otro elemento vinculado con este tipo de turismo: la diferenciación de destinos según la clase social, de tal forma que algunas playas como las de Biarritz atraían a la clase aristocrática y adinerada, y otras como las portuguesas serán del gusto de la clase burguesa media ("La Nación. Cartas de España. Lo de Portugal", p. $7^{\text {I4 }}$ ).

De acuerdo con lo que vamos viendo, los artículos de Pardo Bazán nos valen como testimonio sociológico. Así podemos ver que una de las manifestaciones más interesantes, derivadas de la concentración de este gentío, son las tertulias que afloran en terrazas, locales, rincones variopintos de las playas donde reverberan todo tipo de conversaciones ("La vida contemporánea. San Sebastián", pág. 662 $\left.{ }^{15}\right)$. Pero constata asimismo los elementos negativos de este turismo, como el exceso de calor ("La vida

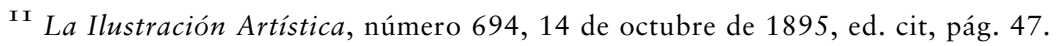

I2 La Ilustración Artística, número 764, 17 de agosto de 1896, ed. cit., pág. 61.

${ }^{13}$ La Ilustración Artística, número 764, 17 de agosto de 1896, ed. cit, pág. 61.

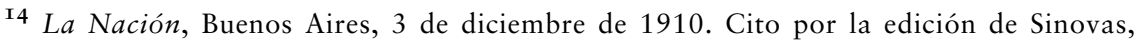
463.

I5 La Ilustración Artística, número 718, 30 de septiembre de 1895, ed. cit., pág. 46.
}

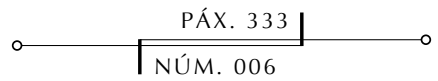


contemporánea. La vida en verano. Cuestión de ropa. San Lorenzo mártir", pág. $538^{16}$; "La vida contemporánea", pág. $458^{17}$ ). A ello suma un peligro más, vinculado con la masificación en los destinos: el incremento en la cantidad de timadores que pretenden aprovecharse de los numerosos extranjeros que visitan nuestro país ("La vida contemporánea", pág. $458^{18}$ ).

La afluencia masiva de extranjeros y el incremento de pillos aparecen asociados, por tanto, con esta época en la que aumenta de forma notable el número de desplazamientos a las playas. Estas se convierten, según lo visto, en un punto de encuentro, donde los efectos beneficiosos del salitre del agua, las conversaciones animadas y los más diversos individuos aparecen como rasgos característicos.

\section{VIAJES EN INVIERNO}

A pesar de la atención que dedica a los viajes realizados durante la primavera y el verano, también menciona los desplazamientos que se producen durante el invierno (caso de "La vida contemporánea. Entrada de invierno", pág. $762^{19}$ ). El turismo de nieve gozará de predicación notable a partir de la II Guerra Mundial, de ahí que no sea tratado en este trabajo. Aun así, como señalo, la autora ratifica la existencia de actividades de ocio turístico durante la época invernal. Con esta época se vinculan también las actividades propias del excursionismo, en tanto que desplazamiento por medios naturales con una intención esencialmente lúdica. A este respecto, resalto la recreación literaria que realiza en textos como Arrastrado $\left(521^{20}\right)$. Poco más dice la autora al respecto; pese a ello, juzgo de interés la inclusión de este apartado, breve excuso sobre actividades en el período invernal, como anticipo de lo que comentaba: el auge de los viajes a la nieve desde la mitad del siglo XX.

\footnotetext{
${ }^{16}$ La Ilustración Artística, número 973, 20 de agosto de 1900, ed. cit., pág. 164.

${ }^{17}$ La Ilustración Artística, número 1333, 15 de julio de 1907, ed. cit., pág. 343.

${ }^{18}$ La Ilustración Artística, número 1176, 11 de julio de 1904, ed. cit., pág. 264.

I9 La Ilustración Artística, número 935, 27 de septiembre de 1899, ed. cit., pág. 145.

${ }^{20}$ Fue publicada en Los contemporáneos ( ${ }^{\circ} 174$, Madrid, 26 de abril). Cito por la edición de Villanueva y González Herrán, 2002: tomo VI.
}

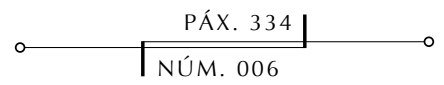


El turismo cultural, desde los románticos (y su predilección por lo exótico) posee un peso específico en el siglo XIX. En la producción de Pardo Bazán encontramos numerosas ciudades que atraen al viajero; ciudades con una añeja historia, con un pasado sugerente, con encanto propio; con un legado cultural fascinador; o, sin más, con festividades que congregan a un público muy diverso. Señala de esta forma algunos de los destinos más atractivos del momento, como Galicia ("La vida contemporánea", pág. 730²1) o Sevilla, cuyos rasgos propios derivados de un crisol de culturas impresionan a los foráneos ("La vida contemporánea. Season", pág. 290²2).

Tomará distintas estampas de la ciudad hispalense en otros textos, como la breve rememoración de su Semana Santa en "En el Escorial" (Por la Europa Católica). La imagen tópica de Andalucía, estrechamente unida a su pasado árabe, se mantiene según se forja con el Romanticismo y los viajeros ingleses y franceses. Pero al tiempo, Sevilla sintetiza las fases propias del desarrollo de un destino turístico: popularización, auge, consolidación y declive. Este último se vincula en especial con la reiteración continua de reclamos sin que estos ser renueven, lo que puede provocar el cansancio del turista que no advierte aliciente nuevo en dicho turismo. Este último estadio lo podemos constatar con el artículo "La Nación. Crónica de España" (pp. 5-6²3).

La reiteración del reclamo turístico conduce a la propagación del tópico y, al cabo, a una actitud distorsionada hacia la cultura española por parte del visitante extranjero. Dicho fenómeno se puede constatar con "Las impresiones de una miss inglesa: España y las mujeres españolas" ${ }^{24}$, que detalla la imagen que de España propagaron ingleses y franceses, la subjetividad de sus impresiones (y remito también con ello al trabajo "Juicios cortos. La España remota", pág. 7525) y la atracción que por ella sintieron (véanse, como muestra, los cuentos "El engaño", 24926, o "Por España", 301²7).

\footnotetext{
${ }^{21}$ La Ilustración Artística, número 1663, 10 de noviembre de 1913, ed. cit., pág. 508.

${ }^{22}$ La Ilustración Artística, número 801, 3 de mayo de 1897, ed. cit., pág. 80.

${ }^{23}$ La Nación, Buenos Aires, 29 de mayo de 1910, ed. cit., 394.

${ }^{24}$ Diario de la Marina, La Habana, 26 de enero de 1913. Cito por la edición de HeydlCortínez, 201-201.

${ }^{25}$ Nuevo Teatro Crítico, año I, número 3, marzo de 1891, ed. cit.

${ }^{26}$ Fue publicado en La ilustración española y americana (número 25, 1908). Cito por la edición de Villanueva y González Herrán, 2005: tomo X.

27 Fue publicado el El liberal (27 de diciembre de 1896). Cito por la edición de Villanueva y González Herrán, 2005: tomo X.
}

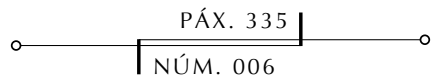


Son muy abundantes los ejemplos en la obra de Pardo Bazán que pueden ilustrar este tipo de turismo cultural. Aparece en sus crónicas sobre Segovia, su Alcázar y el acueducto romano ("A caza del pasado" y "Segovia" en Por la Europa Católica), sobre los que destila comentarios de tipo arqueológico y arquitectónico, con resonancias de textos divulgativos de su época ${ }^{28}$. Y el Escorial ("En el Escorial", Por la Europa Católica), Ileno de impresiones acerca de sus dimensiones, su configuración arquitectónica y las obras de arte que alberga (verbigratia, Tintoretto); Zaragoza y el Pilar ("En Zaragoza", Por la Europa Católica); Barcelona y sus cercanías"29 ("Géneros de puntos", "Colmena", "Santas", "El Cau Ferrat", Por la Europa Católica); Gerona ("Recuerdos de Gerona", Por la Europa Católica). Bien hay que decir que Pardo Bazán lamentará la ausencia de guías preparados, capaces de guiar adecuadamente al viajero, como así dirá en "El viaje por España".

La autora da cuenta asimismo de la geografía murciana, en sus artículos en Letras de molde del año 1900. La huerta, el aspecto semidesértico de Cartagena, su breve estancia en Murcia capital (y su visita al museo, con sus dudas de que conserven realmente obras de Salcillo), Orihuela, Elche, etc.

Asimismo, Toledo, cargada de siglos y encanto, recibe encendidos elogios ("Mi Semana Santa", pág. 530; Por la España Pintoresca; "Días toledanos. A Manuel María de Peralta", pp. 19-20) ${ }^{3 \mathrm{I}}$. Y esta ciudad ocupa un papel destacado en Por la Europa Católica ("Misa vieja", "Más patrañas", "Rincones y callejas", "Las alhajas de la Virgen del Sagrario"), con sus calles angostas recorridas de la mano de instruidos cicerones, y revestidas ahora del empaque místico de sus misas y del halo de la historia semilegendaria del rey Egica.

También Valladolid, y Castilla en general, suma infinitud de encantos que atraen a los viajeros (en Nuevo Teatro Crítico ${ }^{32}$; Por la España Pintoresca).

\footnotetext{
${ }^{28}$ Sobre ello detendré en otro trabajo en preparación.

29 Para una mejor comprensión de los contactos que Pardo Bazán tuvo con Cataluña, véase a Patiño Eirín (1998): "Pardo Bazán dejará el rastro de esa estancia en algunas de las páginas de su nutrida obra de epistológrafa así como en las de sus libros de creación y de viajes, en las que elogiará siempre con fervor la Ciudad Condal, el trasiego y ajetreo de sus calles, que son para ella índice de su laboriosidad, la actividad industrial y artesanal que en su seno se fraguan día a día" (449).

${ }^{\circ}{ }^{\circ}$ Nuevo Teatro Crítico, año I, número 5, mayo de 1891.

${ }^{3 \mathrm{I}}$ Nuevo Teatro Crítico, año I, número 7, julio de 1891. Véase, a modo de comparación, la visión sobre la Semana Santa de Galdós (Carta en La Prensa de Buenos Aires, 18 de mayo 1884).

32 Año I, número 10, octubre de 1891, págs. 69-70.
}

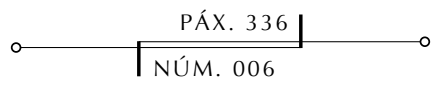


En la obra de Pardo Bazán percibimos una queja reiterada, una crítica manifiesta a determinado rasgo común de gran número de españoles: su escaso (prácticamente nulo) interés por el legado cultural de su nación, o, en general, por los viajes con un mero fin pedagógico ("La vida contemporánea. Desde el tren", pág. 66633; "Cartas de la Condesa (El desinterés de los españoles en el arte de su país)"34; "Las exposiciones", pág. 24)35. De esta forma, muchos viajes de los españoles se producen con la intención de acudir a festejos diversos, marginando los posibles encantos culturales del lugar que visitan. Así lo percibe ella con una manifestación que pervive hasta nuestros días en la ciudad de Santiago de Compostela: los peregrinajes, agudizados durante los prolegómenos, desarrollo y postrimerías de los Años Santos ("La vida contemporánea. Jubileo", pág. $482^{3^{6}}$ ) y la forma en la que se han desvirtuado, obviándose las motivaciones religiosas a favor de la mera diversión ociosa ("El peregrino", págs. 5-1037).

Europa, como lugar de destino, muestra el carácter cosmopolita de la autora. Así, en Mi Romería visita Florencia ("Jornada florentina") para manifestar su asombro ante las riquezas que alberga; o Padua ("Una visita a San Antonio de Papua"), Ancona ("Loreto", en el que describe el santuario del mismo nombre); etc. Pero si hay un destino turístico fundamental en la biografía de Pardo Bazán ese sería, a mi juicio, París. Así encontramos digno testimonio en Al pie de la torre Eiffel, donde se detalla el viaje emprendido en 1889 con motivo de la Exposición Universal. En tal texto se perfilan algunas de las contactos literarios que mantuvo o sus comentarios sobre creadores y pensadores en lengua francesa (Zola, los hermanos Gouncourt, Flaubert, Daudet, Musset, Comte, Bourget, Barbey d'Aurevilly..., por lo que sabemos de la sección "¡Francia! Aquel París"), sus inquietudes culturales (con visitas al Louvre, Cluny, Grevin, la Bastilla...), sus paseos (por el Trocadero, por la Exposición con la inevitable Torre Eiffel, por las fábricas de Sevres y los Gobelinos) y numerosos posicionamientos estéticos, reflejo de su credo

${ }^{33}$ La Ilustración Artística, número 929, 16 de octubre de 1899, ed. cit., pág. 142.

34 Diario de la Marina, La Habana, 20 de abril de 1913, ed. cit., 214.

35 Nuevo Teatro Crítico, año II, número 24, diciembre de 1892, De sumo interés es la visión que aporta Pardo Bazán sobre las Exposiciones Universales. Véase, para ello, a Freire López (1997).

${ }^{36}$ La Ilustración Artística, número 813, 26 de julio de 1897, Ed. cit., pág. 86.

37 Nuevo Teatro Crítico, año I, número 12, diciembre de 1891.

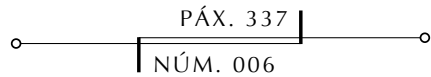


intelectual, de su visión de la literatura y su actitud ante la cultura de manera amplia, fruto de la intuición y de numerosas lecturas; eso sí, sin que se pueda discernir siempre con claridad lo que es fruto genuino de la impresión espontánea de lo que constituye paráfrasis comentada, ampliada y reflexiva de lecturas sobre el tema que trata (esto especialmente abundante), hasta mostrar un significativo prurito de erudición. Pero volviendo al tema que nos ocupa, antes de París pasará también por Burdeos ("En Burdeos", "Un bizantino moderno").

Su visión sobre París y la exposición se mantiene en Por Francia y Alemania, acompañada de comentarios de crónica social e incursiones mundanas (por ejemplo, sus compras), además de numerosas reflexiones culturales (sobre pintura, literatura, teatro, música...). Seguirá su viaje y alcanzará Zurich, Munich, Nuremberg, Karlsbad...

En 1900, para El Imparcial, publica sus crónicas sobre la Exposición Universal que se celebra en París, textos recogidos en el volumen Cuarenta días en la exposición. De nuevo encontramos sus reflexiones culturales de todo tipo (como las arquitectónicas, sobre el puente de Alejandro III, o el Palacio de Industrias, por ejemplo, en la Exposición) y la consignación de lo que en los pabellones de los diferentes países se mostraba (España, Transvaal...).

Viajes por lugares diversos: para recrearse, o amar, o disfrutar, o tal vez olvidar (penas, culpas, obsesiones). Pero junto a las ciudades que reciben esa afluencia continua de viajeros, debemos recordar aquellas otras que sufren el efecto contrario, que son abandonadas a causa de los desplazamientos estacionales y esporádicos de sus habitantes. Este hecho afecta sobre todo a las grandes capitales, incluida la propia París en verano ("La vida contemporánea. Regreso", pág. 698 ${ }^{38}$ ) o Madrid ("La vida contemporánea", pág. 47439; "La vida contemporánea", pág. 49440; "Crónicas de España", p. ${ }^{4 \mathrm{I}}$; "Cartas de la Condesa (Costumbres populares en Madrid durante el verano)", pp. 178-17942; "Mi Semana Santa", pág. 543), debido a las altas temperaturas, si bien tal huida sólo era protagonizada por las clases que se

${ }^{38}$ La Ilustración Artística, número 1035, 28 de octubre de 1901, ed. cit., pág. 198.

39 La Ilustración Artística, número 1491, 25 de julio de 1910, ed. cit., pág. 421.

$4^{\circ}$ La Ilustración Artística, número 1700, 27 de julio de 1914, ed. cit., pág. 528.

${ }^{4 \mathrm{I}}$ La Nación, Buenos Aires, 15 de agosto de 1913, ed. cit., 807.

42 Diario de la Marina, La Habana, 28 de julio de 1912, ed. cit., 178.

43 Nuevo Teatro Crítico, año I, número 5, mayo de 1891

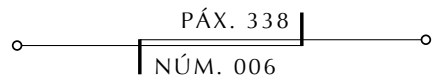


lo podían permitir, permaneciendo en la ciudad la población obrera. Como decíamos al inicio de este artículo, el turismo de masas es un fenómeno propio de la segunda mitad del siglo XX.

Madrid será por tanto reclamo turístico en otras épocas del año, como el otoño ("La vida contemporánea", pág. 19044). El estallido de la I Guerra Mundial favorecerá de forma indirecta a Madrid con destino, dada la neutralidad oficial tomada por España en el conflicto ("Crónica de España. Disquisiciones sobre la guerra", p. $5^{45}$ ). Con la I Guerra Mundial se finiquita toda una forma de ver el turismo netamente elitista, en tanto que la llegada de los felices años veinte propiciarán su popularización. Con todo, serán las medidas adoptadas tras la II Guerra Mundial (ampliación de la cobertura de la seguridad social, limitación de las jornadas laborales, reconocimiento por parte de la ONU del descanso y las vacaciones como derecho fundamental del hombre, emancipación de la mujer...) las que consoliden este fenómeno.

De forma colateral, en los textos de Pardo Bazán se testimonian actividades ligadas al turismo. Una consecuencia asociada a la visita de todas estas ciudades es la compra y envío de postales, para Pardo Bazán expresión de cierta frivolidad ("La vida contemporánea. Marinos. Postales", pág. 66646).

Como cierre, toca de nuevo hablar del excursionismo (en su definición restringida de "visita breve, de unas horas, a un lugar, con una intención de recreo"), ahora ligado al turismo cultural. Una buena muestra nos la ofrece De mi tierra, con el desplazamiento hasta Casdemiro, cuna del padre Feijoo; la visita al monasterio de San Rosendo en Celanova; sus paradas en Mondariz, en especial al castillo de Sobroso; las rutas al cabo del río Sil y la visita al monasterio de San Esteban. En "Impresiones santiaguesas", conocemos sus viajes a Santiago de Compostela, y así nos describe el convento de San Lorenzo; y en "Marineda" ofrece semblanzas de Coruña.

44 La Ilustración Artística, número 1577, 18 de marzo de 1912, ed. cit., pág. 464

45 La Nación, Buenos Aires, 5 de octubre de 1914, ed. cit., 943.

${ }^{46}$ La Ilustración Artística, número 1033, 14 de octubre de 1901, ed. cit., pág. 197.

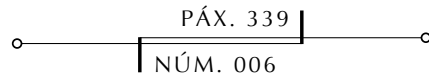




\section{Tribuna}

CADERNOS DE ESTUDOS DA CASA
MUSEO EMILIA PARDO BAZÁN

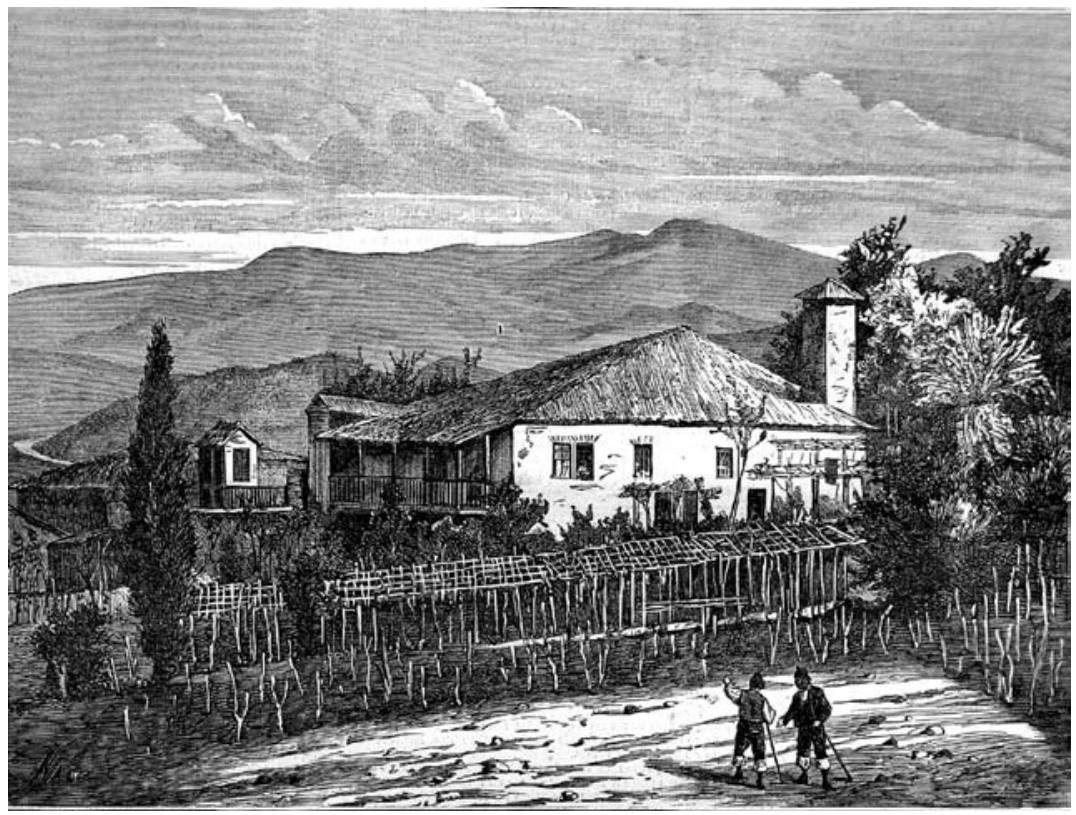

Casa de Casdemiro na que naceu o Padre Feijoo, La Ilustración Gallega y Asturiana 8/10/1880, páxina 356. Biblioteca da Real Academia Galega.

En suma, hallamos otra clase de viajes por placer a través de su obra de ficción. Un tipo muy característico es el viaje de novios, con ejemplos paradigmáticos como la novela Un viaje de novios y la azarosa luna de miel de Aurelio y Lucía, o los textos Mujer (14547) y "Sangre del brazo" (551$552^{48}$ ). De igual forma, en su producción encontramos viajes con un claro fin sentimental: una añoranza, un recuerdo, una escapada amorosa ("Temprano

47 Se publicó en La España Moderna (1895). Cito por la edición de Villanueva y González Herrán, 2002: tomo VI.

${ }^{48}$ Fue publicado en El Imparcial (2 de marzo de 1896), y posteriormente en los Cuentos de amor (Obras completas, tomo XVI, 1898). Cito por la edición de Villanueva y González Herrán, 2004: tomo VIII.

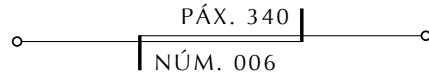




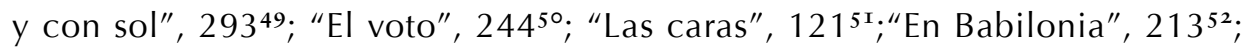
"La casa del sueño", 57553); o la variedad del viaje profesional, que ocasiona emotivas evocaciones con muestras tan ilustrativas como las de Los Pazos de Ulloa (págs. 93, 18154) o La muerte del poeta (58555). En este último grupo destaca el Silvio Lago de La Quimera, que en su recorrido por los países nórdicos experimentará un viraje estético y espiritual (459-49156). Y visita La Haya, Harlem, Ámsterdam, Brujas... Al cabo, semejantes a los anteriores, tenemos otros viajes con los que se pretende olvidar un sufrimiento pasado, o esconder un secreto (Allende la verdad, 31557; "El ruido", 66-6758).

\section{TURISMO TERMAL}

Hemos visto hasta ahora diversos tipos de viajes, originados todos por un fin más o menos prosaico. Junto a ellos, debemos mencionar otro grupo muy característico y definido: el que se motiva por cuestiones de salud, ya sea con un afán preventivo o con una clara intención reparadora que busca atajar algún mal físico o psíquico. Un tipo de turismo muy unido, como ya señalábamos al hablar de los baños de mar, con las teorías higienistas del momento. Remito como introducción, así pues, a lo allí dicho.

\footnotetext{
49 Fue publicado en Cuentos escogidos (1891) y en Cuentos de amor (op. cit.). Cito por la edición de Villanueva y González Herrán, 2004: tomo VII.

${ }^{\circ}$ Fue publicado en El Imparcial (15 de agosto de 1892), y con posterioridad en Cuentos nuevos (Obras Completas, tomo X, 1894). Cito por la edición de Villanueva y González Herrán, 2004: tomo VIII.

${ }^{5}$ Se publicó en El Imparcial (25 de junio de 1906); más tarde aparece en Interiores (El fondo del alma. Interiores, en Obras Completas, tomo XXXI, 1907). Cito por la edición de Villanueva y González Herrán, 2005: tomo X.

$5^{2}$ Apareció en El Imparcial (15 de septiembre de 1902); después, en Sud-exprés (Sudexprés (cuentos actuales), en Obras Completas, tomo XXXVI, 1909). Cito por la edición de Villanueva y González Herrán, 2005: tomo X.

53 Fue publicado en La Ilustración Española y Americana (número 12, 1911) y en los Cuentos de la tierra (en Obras Completas, tomo XLIII, 1922). Cito por la edición de Villanueva y González Herrán, 2005: tomo X.

54 Cito por la edición de Ayala, 2000.

55 Aparece el 28 de marzo en el número 222 de Los contemporáneos. Cito por la edición de Villanueva y González Herrán, 2002: tomo VI.

${ }^{56}$ Aparece en 1903 en La Lectura, y en 1905 fue publicada en el volumen XXIX de las Obras completas de Pardo Bazán. Cito por la edición de Mayoral, 1991.

57 Apareció en El cuento semanal (n ${ }^{\circ}$ 95, Madrid, 23 de octubre). Cito por la edición de Villanueva y González Herrán, 2002: tomo VI.

${ }^{5}$ Apareció en El Imparcial (21 de noviembre de 1892) y en Cuentos nuevos (en Obras Completas, tomo X, 1894). Cito por la edición de Villanueva y González Herrán, 2004: tomo VIII.
}

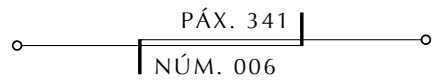


El descanso, común a todos los viajes que estamos describiendo, se une en la presente ocasión a un propósito mucho más práctico, de raíces curativas. En este caso, sobresale un balneario por encima de los demás: Mondariz, de creciente popularidad desde el descubrimiento del manantial de Troncoso en 1862 por el sacerdote Domingo Blanco y de la fuente de Gándara por Enrique Peinador, así como por la Declaración de Utilidad Pública en 1873 (Castillo Campos, 2002).

El interés del balneario radica, según cree la autora, en su localización en tierras gallegas59 ("La vida contemporánea", pág. 63860). Mondariz encabeza la lista de balnearios prestigiosos del territorio español ("Mondariz ejerce una hegemonía en España, como en Francia Vichy, que le pone a salvo de competencias", "Crónicas de España. La enfermedad de moda y el balneario de Mondariz", p. $\left.8^{61}\right)$. Destaca, en primer término, por atraer a un público selecto ("La vida contemporánea. Mondáriz" [sic.], pág. 53862) y oferta unas cuidadas instalaciones ("La vida contemporánea. Mondariz", pág. 538 ${ }^{63}$ ), por lo que quizás congrega a un abundante público ("La vida contemporánea. Hidroterapia", pág. 53864). Con todo, Pardo Bazán testimonia una evidencia que se concreta en el período entre las dos grandes guerras mundiales: la decadencia del turismo termal ("La vida contemporánea", pág. 49065), turismo que inicia su recuperación en las décadas finales del siglo XX.

Pero Pardo Bazán centra también su atención en otros balnearios. Así, el de Ontaneda, en tierras cántabras, tal y como testimonia en Por la España pintoresca, cuyas instalaciones merecen sus elogios. De allí realizará diversas visitas por La Montaña, como el solar de Quevedo, los alrededores del río Pas, Santander (de la que destaca la iglesia subterránea de Cristo, la biblioteca de

\footnotetext{
59 Sus elogios a Galicia reaparecen en otros artículos, como es el caso de "Galicia y sus capitales. (Fisonomías cívicas). I. La Coruña” (en El Heraldo Gallego, núm. 292, 5 de diciembre de 1878, págs. 425-227; núm. 297, 31 de diciembre de 1878, págs. 457 459; núm. 300, 10 de enero de 1879, págs. 19-22), "Bocetos del paisaje gallego" (en La Ilustración Gallega y Asturiana, núm. 11, 18 de abril de 1880, pág. 134) o "De mi tierra [Ribadavia, Melón, Junquera, Allariz, Mezquita]” (en El Imparcial, 13, 27 de noviembre, 11 de diciembre de 1893).

${ }^{6}$ La Ilustración Artística, número 1605, 30 de septiembre de 1912, ed. cit., pág. 478.

6r La Nación, Buenos Aires, 6 de octubre de 1912, ed. cit., 703-705.

${ }^{62}$ La Ilustración Artística, número 869, 22 de agosto de 1898, ed. cit., pág. 113.

63 La Ilustración Artística, número 869, 22 de agosto de 1898, ed. cit., pág. 113.

${ }^{64}$ La Ilustración Artística, número 921, 21 de agosto de 1899, ed. cit., pág. 138.

${ }^{6}$ La Ilustración Artística, número 1439, 26 de julio de 1909, ed. cit., pág. 395.
}

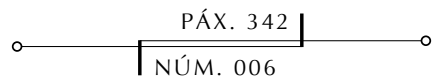


Menéndez Pelayo, la Estación de biología marítima, el Sardinero y el palacete de Galdós), Santillana del Mar (y su abadía, que compara con la gallega de Xunqueira de Ambía), la bulliciosa comercialmente hablando Comillas, o la visita a las Cuevas de Altamira.

También el de La Toja (fundado por José Riestra López, bajo proyecto arquitectónico de Daniel Vázquez Gulías-Martínez) despierta su interés. Los trabajos "La vida contemporánea. Salud en el fango. La Toja" 66 y "Crónicas de España. La Toja" (p. 6 ${ }^{67}$ ) suponen unas buenas referencias para conocer algunas de las actividades que se practicaban en La Toja en el momento, caso de los baños con fango. Con La Toja se demuestra una vez más que era un tipo de turismo para clases acomodadas ("La vida contemporánea", pág. 49068).

Asimismo, alude a balnearios del extranjero, como los suizos ("La Nación. Crónica de Europa", p. 6 ${ }^{69}$ ), o el de Karlsbad ("Unas aguas elegantes", en Por Francia y por Alemania). La vida en los balnearios permite, en suma, realizar una radiografía de los hábitos sociales, la mezcla de "aristócratas, plutócratas, intelectuales, políticos, religiosos, clérigos, militares, médicos, industriales (...), enfermos que no parecen, sanos que se creen enfermos $(. . .)^{\prime \prime}$ ("La vida contemporánea", pág. 55870) y la diversidad de enfermos (como en el cuento "Más allá", 48971).

En síntesis, los balnearios congregan a personas de toda índole; las necesidades de reparar una salud quebrantada, o de buscar un descanso necesario, presentan un patrón democrático capaz de igualar a individuos de todas las clases (exclúyase, por supuesto, la trabajadora).

\section{EXCURSIONISMO: JIRAS CAMPESTRES Y DÍAS DE CAMPO}

En apartados previos se han mencionado diferentes muestras de excursionismo, vinculado a las manifestaciones reseñadas. Merece ahora algún comentario más. De entre todos los desplazamientos que estamos

${ }^{66}$ La Ilustración Artística, número 923, 4 de septiembre de 1899, pág. 570, ed. cit., pág. 139.

${ }^{67}$ La Nación, Buenos Aires, 17 de noviembre de 1912, ed. cit., pág. 713.

${ }^{68}$ La Ilustración Artística, número 1439, 26 de julio de 1909, ed. cit., pág. 395.

${ }^{69}$ La Nación, Buenos Aires, 1 de diciembre de 1911, ed. cit., pág. 598.

$7^{\circ}$ La Ilustración Artística, número 1755, 23 de agosto de 1915, ed. cit., pág. 567.

${ }^{7 \mathrm{I}}$ Apareció en El Imparcial (21 de agosto de 1893) y en Cuentos de amor (op. cit.). Cito por la edición de Villanueva y González Herrán, 2004: tomo VIII.

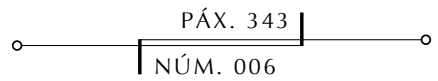




\section{Tribuna \\ CADERNOS DE ESTUDOS DA CASA \\ MUSEO EMILIA PARDO BAZÁN}

viendo, este es uno de los que más interesa a Pardo Bazán. Estamos ante excursiones campestres, paseos por la montaña o visitas a quintas localizadas en el ámbito rural ("La vida contemporánea. De todo", pág. 57072).

Estos desplazamientos también están sometidos a los cambios de gustos, de tendencias; a las mudanzas de los tiempos, en tanto que se han contemplado desde perspectivas deportivas, científicas (exploraciones) o lúdicas (con sus variantes: paseos, fiestas campestres, meriendas...). Nos Ilama la atención, de nuevo, la capacidad de discernimiento de Pardo Bazán, pues sobre todo ello Ilama la atención la autora en "La vida contemporánea" (pág. 53873).

Dentro de este grupo, vemos que la visita a quintas ubicadas en el campo constituye una afición muy arraigada entre algunos individuos (lo vemos, por ejemplo, en la novela corta Cada uno..., 29074). A veces, el viaje al campo está motivado por cuestiones médicas, ante la necesidad de curar una salud débil (así, en el cuento "Bucólica", 6175) o, simplemente, puede deberse a alguna afición, como la caza (en el relato "Maldición de gitana", 53776).

Tal afición despierta el hambre de los excursionistas ("Nube de paso", $\left.423^{77}\right)$ y se reseñan los efectos benéficos del hoy popularizado senderismo ("Sequía", 707-70878; "El fondo del alma", 579; "La leyenda de la torre", $497^{8 \circ}$ ) y el gusto por la mera contemplación del paisaje; eso sí, ubicados los paseantes en un cómodo carruaje ("Leliña", 198I).

72 La Ilustración Artística, número 1131, 31 de agosto de 1903, ed.cit., pág. 243.

73 La Ilustración Artística, número 1129, 17 de agosto de 1903, ed. cit., pág. 242.

74 Fue publicado en El cuento semanal ( $\mathrm{n}^{\circ} 7$, Madrid, 15 de febrero). Cito por la edición de Villanueva y González Herrán, 2002: tomo VI.

75 Apareció en 1885. Cito por la edición de Villanueva y González Herrán, 2004: tomo VII.

${ }^{76}$ Apareció en El Liberal (5 de septiembre de 1897) y en Cuentos de amor (op. cit.). Cito por la edición de Villanueva y González Herrán, 2004: tomo VIII.

77 Apareció en La Ilustración Española y Americana (número 22, 1911) y en Cuentos trágicos (1912). Cito por la edición de Villanueva y González Herrán, 2005: tomo X.

${ }^{78}$ Apareció en El Imparcial (28 de enero de 1895) y en Cuentos sacroprofanos (Obras Completas, tomo XVII, 1899). Cito por la edición de Villanueva y González Herrán, 2004: tomo VIII.

79 Apareció en El Imparcial (11 de junio de 1906) y en Cuentos del terruño (Obras Completas, tomo XXXI, 1907). Cito por la edición de Villanueva y González Herrán, 2005: tomo X.

${ }^{80}$ Apareció en Cuentos trágicos (1912). Cito por la edición de Villanueva y González Herrán, 2005: tomo X.

${ }^{8 \mathrm{I}}$ Fue publicado en El Imparcial (2 de febrero de 1903) y en Cuentos del terruño (op. cit.). Cito por la edición de Villanueva y González Herrán, 2005: tomo X.

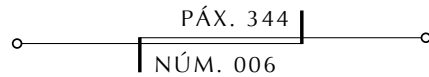


La caza, el senderismo, el pequeño paseo, el retiro en la quinta y la excursión en calesa son diferentes expresiones de una misma intención: la huida de la ciudad por parte de individuos deseosos de alcanzar la influencia positiva del mundo rural.

\section{EL PROBLEMA DE LOS MEDIOS DE TRANSPORTE}

Viajar es una actividad instructiva, sana, necesaria. Tales son las conclusiones que se desprenden de lo que hemos visto hasta ahora. Pero viajar, además, puede arrostrar incomodidades, quebraderos de cabeza y disgustos insufribles. Viajar acarrea romper la rutina, con sus consecuencias. Pardo Bazán, tan prolija en sus elogios a los días de asueto, arremete contra un enemigo para ella inclemente: las complicaciones en los desplazamientos. Veremos en el siguiente punto un adversario más: los alojamientos inadecuados.

El desarrollo del turismo está muy ligado a la mejora de los medios de transporte. Así, la revolución industrial fue determinante; recordemos hitos como la creación de las líneas París-Dieppe o Mataró-Barcelona en 1848. La implementación del ferrocarril abarata los costes del desplazamiento, ahora asumibles por una emergente clase media (en especial, en Inglaterra), a lo que da respuesta la aparición de la primera agencia de viajes conocida, la de John Mason Cook en 1865. En el caso español, en el año 1870 se contaba con $5316 \mathrm{~km}$ de red de ferrocarril y 11.039 de vía ancha (y 2.166 de vía estrecha) en $1900^{82}$. Es la ley de ferrocarriles de 1855 (firmada por el ministro de Fomento Francisco de Luxan durante el reinado de Isabel II) la que condiciona en gran medida el desarrollo del ferrocarril (aranceles; ancho de vía, de 1’67 m, frente al 1'435 europeo; empresas concesionarias; etc $)^{83}$.

De entre todos los medios de transporte disponibles para viajar, el que más suscita la queja de la autora es el tren ${ }^{84}$. Los inconvenientes aparecen incluso, a su modo de ver, antes de llegar a la estación ("La vida contemporánea", pág.

\footnotetext{
${ }^{82}$ Fuente: Albert Carreras y Xavier Tafunell (coords.) (2005).

83 En el caso de las empresas que reciben la concesión, le concede el artículo 20 los terrenos por los que pase el ferrocarril, y el cobro de derechos de peaje y transporte (Ley General de Caminos de Hierro, 1855).

${ }^{84}$ Acotamos la información al respecto a los intereses del presente artículo y a las limitaciones consiguientes. Para una visión más completa sobre la presencia del tren en la obra de Emilia Pardo Bazán, véase el artículo de González Herrán (1996).
}

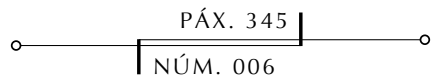


$\left.474^{85}\right)$. Las deficiencias de los ferrocarriles de la época eran notables, a lo que se añadían las deficiencias de gestión administrativa. Pardo Bazán señala que el primer paso, la compra del billete y la subida al vagón, constituía, ya de por sí, toda una odisea ("La vida contemporánea. De viaje", pág. 634 ${ }^{86}$ ). De igual interés sociológico son los numerosos consejos que ella ofrece a los usuarios del ferrocarril, entre los que podemos destacar la necesidad de inventariar el contenido del equipaje para después facilitar la correspondiente reclamación en caso de pérdida, las adecuadas medidas de seguridad al incorporarse al tren o la necesaria precaución ante posibles sustracciones ("La vida contemporánea. Llegada", pág. 746 ${ }^{87}$ ), no digamos ya la manera de afrontrar los comunes e insufribles retrasos ("La vida contemporánea. Desde el tren", pág. $666^{88}$ ), la manera de acomodarse en los erróneamente distribuidos coche-cama o la forma de acudir al vagón-restaurante sin encontrar allí una muchedumbre ("La vida contemporánea", pág. 44689).

En conjunto, percibimos que la crítica a los ferrocarriles españoles es común en Pardo Bazán, como se ve en textos del tipo de Por la Europa Católica (así, en "Desde el tren"). En "El viaje por España" (publicado como se ha dicho en La España Moderna) anota la reprobable tendencia española a imitar la organización de los ferrocarriles franceses, imitación en cualquier caso imperfecta (ausencia de vagones para no fumadores, inadecuadas infraestructuras, informalidad en los horarios...), hechos que inciden en que no se publique la conocida Guía Boedeker, por la que por cierto mostrará aprecio en otras ocasiones (como en "Un cicerone gratis", en Mi Romería). Muy revelador es su grito, al inicio del segundo capítulo de Por la Europa Católica: “¡Europeicémonos!”. Comparaciones con lo francés que proliferan en su obra (recuérdese, como muestra, "París necesita rey", en Al pie de la torre Eiffel). Pese a todas estas deficiencias que detecta en los ferrocarriles, no deja de proporcionarnos una visión positiva; así ocurre con el viaje de la familia Leyva en la pieza teatral El becerro de metal, donde estos gozan de numerosas comodidades: un servicio eficaz (el marqués toca un timbre y de inmediato aparece un mozo para servirles: pág. 1703) y un amplio vagón donde conversa la familia con sus conocidos ${ }^{90}$.

\footnotetext{
${ }^{85}$ La Ilustración Artística, número 1125, 20 de julio de 1903, ed. cit., pág. 240.

${ }^{86}$ La Ilustración Artística, número 875, 3 de octubre de 1898, ed. cit.pág. 116.

${ }^{87}$ La Ilustración Artística, número 1090, 17 de noviembre de 1902, ed. cit., pág. 224.

${ }^{88}$ La Ilustración Artística, número 929, 16 de octubre de 1899, ed. cit., pág. 142.

${ }^{89}$ La Ilustración Artística, número 1697, 6 de julio de 1914, ed. cit., pág. 526.

90 Cito por la edición de F. Sáinz de Robles (1964).
}

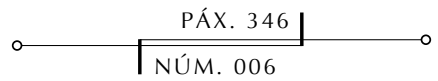


En "La vida contemporánea" (pág. 3669I), a tenor de un viaje en automóvil, constata las tres bases de los problemas del turismo en España, objetivos que se esperaba erradicar en las primeras décadas del siglo XX con la creación de la Comisaría Regia de Turismo, el Patronato Nacional de Turismo o la Dirección General del Turismo (en sucesivas etapas). Estas son las deficiencias en las estructuras (incluida la falta de preparación de los caminos), el despoblamiento del territorio español (que redunda en las carencias a la hora de ofrecer un servicio turístico) y la falta de preparación de los servicios hosteleros.

Aunque no puede olvidársenos que los viajes en automóvil no eran tampoco del agrado de la autora coruñesa ${ }^{92}$. En su época, la red de carreteras española nace en el siglo XX, como necesidad al creciente transporte rodado con el auge del automóvil, y contaba en 1898 con 34.000 km (en su mayoría aptos para la circulación de vehículos de tracción animal, pero no de tracción a motor) y en 1900 con poco más de 36.000, mientras que en 1924 alcanzará casi los 56.000. Recordemos simplemente que es la Real Orden de 31 de julio de 1897 la que autoriza la circulación de vehículos ${ }^{93}$, y poco después se exigirá su matriculación. Lo que se percibe, a través de la legislación del momento, es la lentitud de las autoridades a la hora de regular el uso de este nuevo medio de transporte, así como la ineptitud a la hora de de facilitar las adecuadas infraestructuras para su circulación.

Quizás de lo visto en este punto podamos concluir que para la escritora gallega no existe un medio de transporte idóneo; los que ella comenta presentan limitaciones que ocasionan incomodidades al viajero, lacras ligadas en gran medida al deficiente servicio prestado.

${ }^{1}$ La Ilustración Artística, número 1744, 31 de mayo de 1915, ed. cit., pág. 558.

92 Véanse, a este respecto, los siguientes artículos: "La vida contemporánea", La Ilustración Artística, número 1119, 8 de junio de 1903, pág. 378 -ed.cit., pág. 237; "La vida contemporánea”, La Ilustración Artística, número 1380, 8 de junio de 1908, pág. 378 -pág. 366 de la edición facsimilar citada; "La vida contemporánea”, La Ilustración Artística, número 1388, 3 de agosto de 1908, pág. 506 -pág. 370 de la edición facsimilar; "La vida contemporánea", La Ilustración Artística, número 1551, 18 de septiembre de 1911, pág. 606 -pág. 451 de la edición facsimilar; "La vida contemporánea", La Ilustración Artística, número 1823, 4 de diciembre de 1916, pág. 778 -pág. 612 de la edición facsimilar; "Crónicas de España”, en La Nación, Buenos Aires, 26 de agosto de 1919, pág. 4 -ed. cit., pág. 1330); “Adelante”, en Cuarenta días en la Exposición.

93 El Real Decreto de septiembre de 1900 la modifica. Los artículos 3 y 4, por ejemplo, exigen algunas de sus características técnicas y de identificación (frenos, piezas, tubos, datos de constructor y propietario...), y el $5^{\circ}$ establece la necesidad de que el conductor posea de un permiso expedido por el gobernador de la provincia correspondiente. 


\section{INSTALACIONES HOTELERAS}

En este punto, Pardo Bazán observa, con pasmo, las deficiencias de algunas infraestructuras, las carencias de determinados alojamientos y las bastedades del sector de la hostelería. Un inconveniente más que puede agriar el tan ansiado viaje, caso de la Fonda do Brazileiro en Galicia ("Crónicas de España. La enfermedad de moda y el balneario de Mondariz", p. ${ }^{94}$ ). También posadas y fondas son objeto de su crítica, debido a su atraso, en su visión de Castilla (Por la Europa Católica); y en "El viaje por España" (La España Moderna, 1895) la autora declara la disparidad de alojamientos a los que se puede optar en el territorio europeo, como el albergo y la ostería en el caso italiano, las maisons de familla y las pensions bourgeoises en el francés. El caso español ofrece abundantes ejemplos de malas imitaciones de los alojamientos franceses, para lo que ofrece casos concretos, como el "Términus" de Bilbao, síntesis de los problemas que aquejan a la hostelería española: deficientes instalaciones, poco preparado servicio, anomalías en las cuentas entregadas al cliente.

A lo largo de su producción periodística notamos otras deficiencias relacionadas con la hostelería, alguna de ellas vinculadas con hechos azarosos, como la irrupción de la I Guerra Mundial, que implica carestías en el abastecimiento de determinados productos, como el pan ("La vida contemporánea", pág. 54295).

Al mismo tiempo, Pardo Bazán se sitúa muy próxima al pensamiento moderno acerca de la organización del turismo y su enfoque desde postulados de márketing (que no se consolida como planteamiento fundamental en la economía de la empresa hasta la segunda mitad del siglo XX), en tanto que destaca la figura del consumidor, del cliente, cuyas necesidades hay que satisfacer (y así lograr su fidelidad y el consiguiente ingreso económico). "El viajero paga", dice Pardo Bazán ("La vida contemporánea", pág. 67096), y ahí debemos encontrar la clave interpretativa del turismo moderno: el que paga, exige. El nivel de exigencia creciente del consumidor y la regulación pública (ya hemos hablado de la creación del Patronato Nacional de Turismo, por ejemplo; sintomático ejemplo de una creciente regulación que tendrá

${ }^{94}$ La Nación, Buenos Aires, 6 de octubre de 1912, ed. cit., 703-705.

95 La Ilustración Artística, número 1703, 17 de agosto de 1914, ed. cit., pág. 530.

${ }^{96}$ La Ilustración Artística, número 1607, 14 de octubre de 1912, ed. cit., pág. 479.

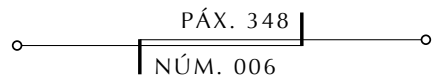


un punto culminante entre los años 60-70 del siglo XX) redundarán en la mejora de instalaciones y servicios. Un proceso que fue lento e inseguro, como podemos ejemplificar de nuevo con Pardo Bazán y sus instantáneas periodísticas del momento (anoto, de muestra, el caso de "Crónicas de Madrid. Los hoteles y la vida del hotel. La "cuesta de enero»", p. 897; o el de "La vida contemporánea", pág. 90989).

Pese a todo ello, la época de la autora todavía está lejos de una regulación adecuada del sector del hospedaje. Hasta la guerra civil, tuvo una labor básica de fomento, y en menor medida de sanción, mientras que la inspección y control de precios fue leve, inconstante $y$, muchas veces, inexistente.

\section{VIAJEROS ILUSTRES}

Como colofón a todo lo que se ha ido comentando, citaré (a modo anecdótico) la atención que presta Pardo Bazán a determinados viajeros ilustres. Entre ellos menciona, por ejemplo, a miembros de la Realeza, como el caso de Alfonso XIII y su familia, que popularizan ciertos destinos, especialmente la costa vasca. Esta tendencia a seguir los gustos de las clases poderosas era ciertamente habitual; recordemos por ejemplo la fama de Biarritz en tanto que destino predilecto de Napoleón III, o la del balneario de Karlovy Vary frecuentado por la aristocracia europea.

Como venía diciendo, Pardo Bazán destaca los diversos viajes de la familia real y su poder de reclamo a otros turistas (recordemos que estos son siempre pudientes) ("La vida contemporánea", pág. 23499; "La vida contemporánea", pág. 266 ${ }^{100}$; "Crónica de España. El monumento a la Reina María Cristina", p. $\left.9^{\text {IOI }}\right)$.

En buena parte de sus trabajos, y a consecuencia de las visitas de la familia real, vemos que San Sebastián destacaba como destino en 1900 (manteniendo la fama adquirida en la segunda mitad del siglo

\footnotetext{
97 La Nación, Buenos Aires, 9 de marzo de 1913, ed. cit., pág. 751.

${ }^{8}$ La Ilustración Artística, número 1623, 3 de febrero de 1913, ed. cit., pág. 487.

99 La Ilustración Artística, número 1162, 4 de abril de 1904, ed. cit., pág. 257.

${ }^{\text {I }}$ La Ilustración Artística, número 1164, 18 de abril de 1904, ed. cit., pág. 258.

Ior La Nación, Buenos Aires, 3 de noviembre de 1913, ed. cit., 839.
}

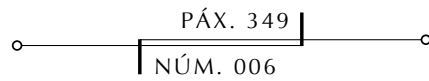


XIX), como muestra Cuarenta días en la Exposición ("No sólo Madrid es corte", "De San Sebastián a París en barco de vapor"). Entre los miembros viajeros de la familia real resalta el caso de la Infanta Francisca de Borbón, hija de Isabel II ("La Nación. Crónica de España. La Infanta Isabel", p. $5^{102}$.

Junto a los aristócratas, intelectuales y artistas caen en las redes de los viajes. Así sucede con el pintor Beruete y sus diversos viajes por España: la cordillera cantábrica, Mallorca, Segovia, Cercedilla... ("La vida contemporánea", pág. $286^{\text {103 }}$ ); o Huntington y su afición por España ("Crónicas de España. Los dramas de amor-Un hispanista", p. $5^{\text {104 }}$ ); y muchos otros: Mackenzie Wallace, Pauloysky (corresponsal ruso del Novoie Wremia de San Petersburgo), Boris de Tannenberg..., todos ellos declarados hispanófilos ("Crónicas de España", p. $\left.5^{105}\right)$.

Unos y otros dibujan, en suma, la variada estampa del turismo español a ojos de Emilia Pardo Bazán. Vienen ahora las necesarias conclusiones.

\section{CONCLUSIONES}

Cansados después de nuestro recorrido, con el sudor (quizás) en la frente, alcanzamos la meta de nuestro viaje. Conviene ahora desprendernos del pesado fardo que hemos ido cargando a lo largo de las últimas páginas. Y, entonces, decir adiós.

Pardo Bazán, incansable autora, nos ha dejado una interesante producción de libros de viajes. Gran parte de ésta nace de la recopilación de diferentes artículos publicados en la prensa periódica. Nuestro trabajo se ha ocupado de ellos y de algunas otras referencias de la autora que no aparecen en dichos libros, además de textos literarios. Con ello pretendía, desde un enfoque antropológico y netamente sociológico, abordar los datos que la autora nos ofrece sobre el fenómeno del turismo en su época (segunda mitad del XIXcomienzos del siglo XX) y así dibujar una estampa ilustrativa de lo que fue tal fenómeno en dicho momento.

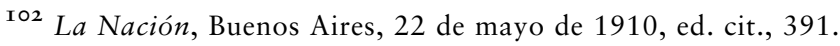

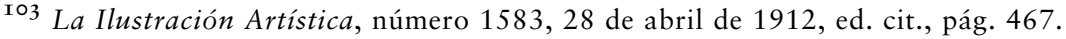

${ }^{\text {I }} 4$ La Nación, Buenos Aires, 23 de julio de 1912, ed. cit., 681.

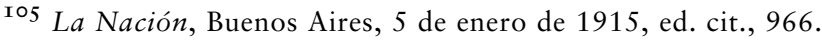

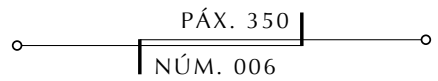




\section{Tribuna}

CADERNOS DE ESTUDOS DA CASA
MUSEO EMILIA PARDO BAZÁN

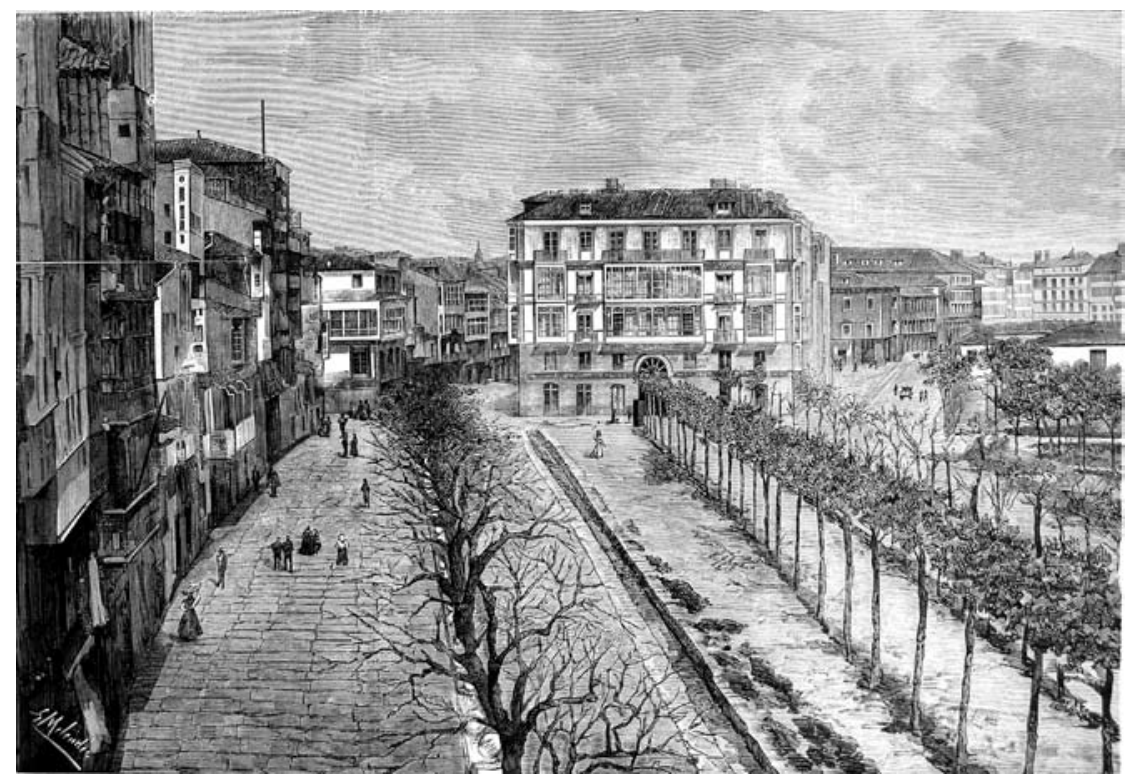

Vista do Cantón de Porlier e dos Xardíns de Méndez Núñez na Coruña. La Ilustración Gallega y Asturiana, 20/08/1879, páxina 278. Biblioteca da Real Academia Galega. 
De artículo podemos extraer varias conclusiones:

1. Evidencian sus textos un dato sobradamente destacado en los estudios de turismo sobre el XIX: el viaje por placer se relaciona con clases pudientes; faltan todavía varias décadas para el nacimiento del turismo de masas.

2. La clase aristocrática detenta gran parte de este tipo de movimientos debidos al factor ocio. Poco a poco lo hace también la clase burguesa, bien es cierto que todavía imbuida de una cultura propia de la Revolución industrial que contempla ocio como oposición de trabajo, prevaleciendo la estima dada a este último como generador de riqueza. Algo similar defendían las doctrinas calvinistas desde el siglo XVIII.

3. La época de Pardo Bazán supone el origen del turismo como fenómeno extendido y en vías de planificación. La obra de la autora lo ejemplifica: aparición de guías de viaje, folletos informativos, rutas organizadas, eventos de divulgación turística, etc.

4. El desarrollo de los medios de transporte facilita los viajes por placer. La autora nos ilustra el caso de ferrocarriles y automóviles, fundamentalmente.

5. Destaca el interés de Emilia Pardo Bazán por la geografía española, y se nota su amplio conocimiento de la misma: Galicia, La Montaña, la región catalana, la región murciana, etc.

6. La autora gallega se convierte en paladín del turismo cultural, el turismo de piedras viejas y rincones añejos, de siglos adormecidos en ciudades vetustas. Al mismo tiempo, sus textos, siendo testimonio de lo anterior, introducen abundantes reflexiones de tipo artístico (corrientes pictóricas, tendencias arquitectónicas, escuelas o autores).

7. Asimismo testifica el escaso interés del español medio por viajes como los anteriormente citados, frente a la popularización de manifestaciones mucho más prosaicas: ferias, romerías, verbenas y festejos diversos.

8. Estrechamente vinculada con lo anterior se encuentra la denuncia de la autora gallega acerca del modo en que se han desvirtuado los viajes con fines religiosos: las peregrinaciones, tocadas antaño por un encomioso afán de sacrificio, autosuperación y fe, han sido desplazadas por viajes en los que parece primar el gusto por el bullicio y la fiesta.

9. Reconoce además el éxito de que gozan determinados viajes durante

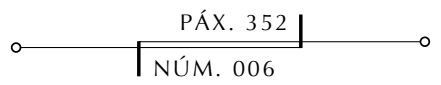


épocas del año como la primavera y el verano. Con la llegada del calor y del sol, el destino preferido es la playa. De igual modo, a través de ella, testimoniamos los dos destinos hispánicos más relevantes en lo que afecta al turismo heliotrópico: las costas vasca y cántabra.

10. Como envés de lo dicho, testifica el abandono que experimentan algunas ciudades durante estas épocas. Madrid o París se deleitan en esos momentos con una inusitada paz. Estas ciudades presencian la llegada de viajeros en momentos puntuales, como la época otoñal.

11. Al lado del "turismo del calor", sobresalen aquellos viajes que buscan la regeneración física, y por lo tanto determinados por un afán higiénico y médico. Los balnearios se presentan como centro de descanso y cura. Se destaca entre los españoles a Mondariz; entre los extranjeros, a los suizos.

12. Pero además de viajes de cierta duración, Pardo Bazán alude a desplazamientos ocasionales, relacionados con el fin de semana o los días festivos: jornadas de caza, excursiones campestres, temporadas en la quinta del pueblo o rutas en carruaje.

13. Todas estas actividades implican a individuos de la más variada condición: burgueses, aristócratas (incluyendo a la familia de Alfonso XIII), artistas o intelectuales.

14. Observamos así a viajeros de todo tipo de catadura hacia destinos variopintos. Estos viajeros aparecen sometidos al yugo de las mismas circunstancias: Ios avatares del viaje. La escritora gallega reflexiona sobre los preparativos, las dificultades del transporte (trenes que no aparecen, o que se retrasan, o que ofrecen servicios deficientes; automóviles en rutas tortuosas sin que cuenten con las necesarias medidas de seguridad), o las condiciones del alojamiento (tipos, deficiencias y mejoras).

Tras esta breve recapitulación concluye nuestro viaje: después de Toledo, Sevilla, Valladolid, París, Madrid; después de algún que otro tren que no llega y más de un camino pedregoso; después de encontrarnos con extranjeros fascinados por nuestra patria, o indignados ante ciertas costumbres; después, en suma, de preparar convenientemente la maleta (la autora gallega comparte instructivos consejos) y de deshacerla otras tantas veces. Llega ya, por fin, el merecido descanso en el que había sido el punto de partida. Recostados en un rincón del hogar, nada mejor que la tranquilidad que ofrece un oportuno silencio. 


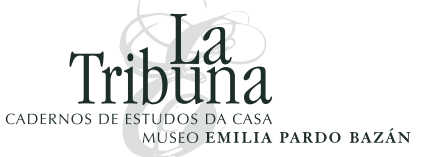

BIBLIOGRAFÍA

Bibliografía sobre Emilia Pardo Bazán:

\section{A.1: Cuentos:}

- Obras completas, VII: La dama joven, Cuentos escogidos, Cuentos de Marineda (2003): edición de D. Villanueva y J. M. González Herrán, Madrid, Biblioteca Castro.

- Obras completas, VIII: Cuentos nuevos. Arco iris. Cuentos de amor. Cuentos sacro-profanos (2005): edición de D. Villanueva y J. M. González Herrán, Madrid, Biblioteca Castro.

- Obras completas, IX: Un destripador de antaño (Historias y cuentos de Galicia). En tranvía (Cuentos dramáticos). Cuentos de Navidad y Reyes. Cuentos de la patria. Cuentos antiguos. Lecciones de literatura (2005): edición de D. Villanueva y J. M. González Herrán, Madrid, Biblioteca Castro.

- Obras completas, X: El fondo del alma. Sud-exprés (Cuentos actuales). Cuentos trágicos. Cuentos de la tierra (2005): edición de D. Villanueva y J. M. González Herrán, Madrid, Biblioteca Castro.

\section{A.2: Novelas:}

- Un viaje de novios (1971): edición de M. Baquero Goyanes, Madrid, Labor.

- Los Pazos de Ulloa (2002): edición de Ma . de los Ángeles Ayala, Madrid, Cátedra.

- Insolación (2001): edición de Ermitas Penas, Madrid, Cátedra.

- La Quimera (1991): edición de M. Mayoral, Madrid, Cátedra.

\section{A.3: Novelas cortas:}

- Mujer (2002): Obras completas, VI, edición de D. Villanueva y J. M. González Herrán, Madrid, Biblioteca Castro, pp. 141-191.

- Cada uno... (2002): Obras completas, VI, edición de D. Villanueva y J. M. González Herrán, Madrid, Biblioteca Castro, pp. 261-297.

- Allende la verdad (2002): Obras completas, VI, edición de D. Villanueva y J. M. González Herrán, Madrid, Biblioteca Castro, pp. 299-340.

- Arrastrado (2002): Obras completas, VI, edición de D. Villanueva y J. M. González Herrán, Madrid, Biblioteca Castro, pp. 485-528. 
- La muerte del poeta (2002): Obras completas, VI, edición de D. Villanueva y J. M. González Herrán, Madrid, Biblioteca Castro, pp. 581-627.

\section{A.4. Teatro:}

- El becerro de metal (1964): Obras Completas, edición de F. Sáinz de Robles, Madrid, Aguilar, tomo I.

\section{A.5. Textos periodísticos:}

- Nuevo Teatro Crítico (1891-1893): Madrid, La España Editorial.

- La obra periodística completa en La Nación de Buenos Aires (1879-1921) (1999): edición de J. Sinovas Maté, A Coruña, Diputación Provincial de A Coruña, 2 vols.

- Cartas de la Condesa en el Diario de la Marina. La Habana (1909-1915) (2002): edición de C. Heydl-Cortínez, Madrid, Editorial Pliegos.

- La vida contemporánea (2005): edición facsimilar de C. Dorado, Madrid, Hemeroteca Municipal de Madrid, Testimonio de prensa, número 5.

6. Libros de viajes:

- Apuntes de un viaje. De España a Ginebra (1873) (inédito)

- Mi romería (1888): Madrid, Imprenta y Fundición de M. Tello.

- De mi tierra (1888): Coruña, Tipografía de la Casa de Misericordia.

- Al pie de la torre Eiffel (1889): Madrid, La España Editorial.

- Por Francia y por Alemania. Crónicas de la Exposición (1889): Madrid, La España Editorial.

- Por la España pintoresca. Viajes (1896): Barcelona, López Editor, Librería Española, Colección Diamante.

- Cuarenta días en la exposición (1901): Madrid, Prieto y Compañía Editores, Obras Completas, tomo XXI.

- Por la Europa católica (1902): Madrid, Administración.

7. Otros textos:

DE PARDO BAZÁN:

- La leyenda de la Pastoriza (1887): La Coruña, José Míguez Peinó y Hermanos (impresores).

DE OTROS AUTORES:

- Pérez Galdós, Benito (1972): Los artículos de Galdós en La Nación. 18651866, 1868, edición de William H. Shoemaker, ínsula, Madrid.

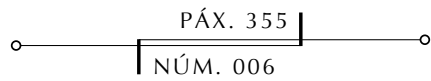


Buenos Aires, edición de William H. Shoemaker, Madrid, Ediciones de Cultura Hispánica.

industrial.

(1981): Galdós, periodista, Madrid, Banco de Crédito Industrial.

BIBLIOGRAFÍA DE CARÁCTER GENERAL

\section{SOBRE PARDO BAZÁN:}

- Carrasco, N. (2007): «Emilia Pardo Bazán, novelista y viajera. Las crónicas de la Exposición Universal », en J. M. González Herrán, C. Patiño Eirín y E. Penas Varela (eds.): Emilia Pardo Bazán: el periodismo, RAG-Fundación Caixa Galicia, Coruña, pp. 341-348.

- Freire López, A. M. ${ }^{a}$ (1997): "Les Expositions Universelles du XIXe siècle dans la Littérature espagnole: La vision d’Emilia Pardo Bazán», en Vision de I'Autre dans une Europe des cultures aux XVIII ${ }^{e}$, XIX $X^{\mathrm{e}}$ et XXe siècles, Les Cahiers du CICC, no 3, Mai, págs. 124-133.

(1999): «Los libros de viajes de Emilia Pardo Bazán: el hallazgo del género en la crónica periodística», en Salvador García Castañeda, (ed.), Literatura de viajes. El Viejo Mundo y el Nuevo, Madrid, Castalia-Ohio State University, págs. 203-212.

- González Herrán, J. M. (1996): «Trenes en el paisaje (1872-1901). Pérez Galdós, Ortega Munilla, Pardo Bazán, Pereda, Zola, Alas», en Darío Villanueva y Fernando Cabo Aseguinolaza (eds.): Paisaje, Juego y Multilingüismo, $X$ Simposio de la Sociedad Española de Literatura General y Comparada, Santiago de Compostela, Universidad de Santiago de Compostela, I, pp. 345358.

(1999): «Un inédito de Emilia Pardo Bazán: Apuntes de un viaje. De España a Ginebra (1873)» en Salvador García Castañeda, (ed.): Literatura de viajes. El Viejo Mundo y el Nuevo, Madrid, Castalia-Ohio State University, págs. 177-187.

- ________ (2000): "Adanzas e visións de dona Emilia (A literatura de viaxes de Pardo Bazán)», Revista Galega do Ensino, 27, págs. 37-62.

- Patiño Eirín, C. (1998): "La aventura catalana de Pardo Bazán", en L. F. Díaz Larios y E. Miralles (eds.): Sociedad de Literatura Española del Siglo XIX. $1^{\circ}$ coloquio (Barcelona, 1996). Del Romanticismo al Realismo, Barcelona, Universitat de Barcelona, pp. 443-455.

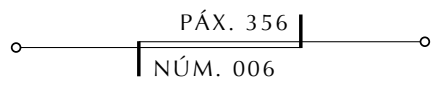


- Rubio Jiménez, J. (2001): “Un viaje olvidado de Emilia Pardo Bazán «Por tierras de Levante»", Murgetana, 105, pp. 93-111

\section{SOBRE TURISMO:}

- Anderson, N. (1975): Trabajo y ocio. Sociología del ocio y el trabajo, Madrid, Edersa.

- Castillo Campos, M. J. (2002): Historia del balneario de Mondariz hasta 1936, tesis doctoral en CD-Rom, Madrid, Universidad Complutense de Madrid.

- Cohen, E. (1974): "Who is a Tourist? A Conceptual Clasification", Sociologycal Review, 39, 64-82.

- Fernández Fúster, L. (1991): Historia general del turismo de masas, Alianza, Madrid, Universidad textos.

- Carreras, A. y X. Tafunell (coords.) (2005): Estadísticas históricas de España (siglos XIX-XX), Bilbao, Fundación BBVA.

- Larrinaga Rodríguez, C. (2002): "El turismo en la España del siglo XIX", Historia Contemporánea, 25, pp. 157-179.

- "Ley General de Caminos de Hierro, 3 de junio de 1855" (6 de junio de 1855): Gaceta de Madrid.

- Murphy, P. E. (1985): Tourism: a Community Aproach, New York, Methuen, National Tourism Policy Study.

- Ryan, C. (1991): Recreational Tourism. A Social Science Perspective, New York, Routledge.

- Sánchez Blanco, V. (1995): "Antecedentes históricos, evolución y situación actual de la red de carreteras española", Cuadernos de estrategia, 78, pp. 19-30.

- Tezanos, J.F. (2003): La explicación sociológica: una introducción a la sociología, Madrid, Uned, Cemav, Madrid. 


\section{Tribuna}

CADERNOS DE ESTUDOS DA CASA

MUSEO EMILIA PARDO BAZÁN

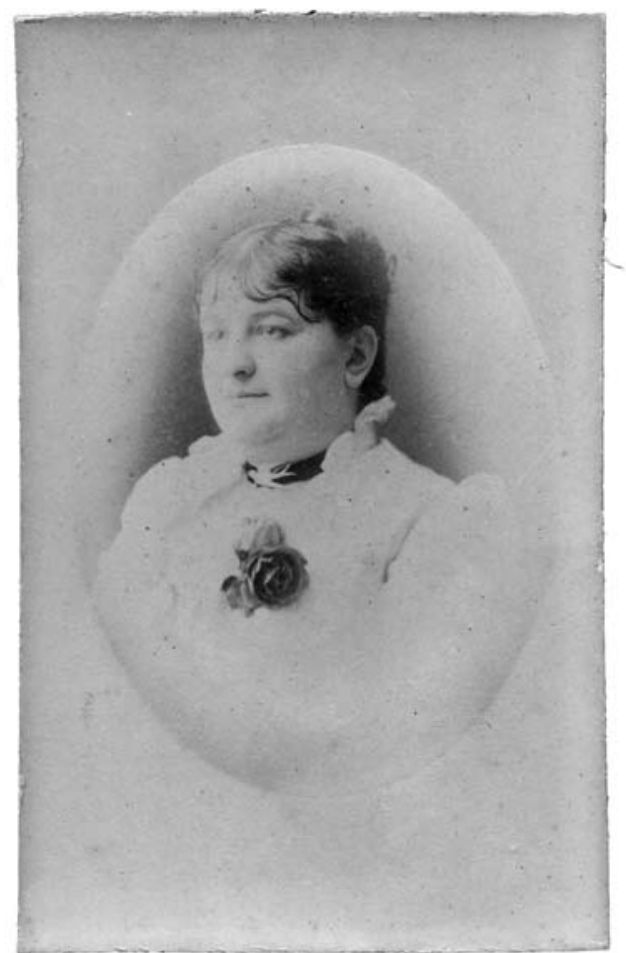

Emilia Pardo Bazán. Arquivo da Real Academia Galega

PÁX. 358

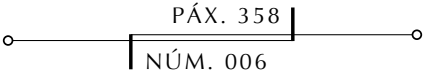

